\title{
The Impact of the Emergence of Eurasian Art Communities in the Globalizing World
}

\author{
Munira Shahidi \\ Z. Shahidi International Foundation, Dushanbe, Tajikistan
}

\begin{abstract}
Eurasian art study is an interdisciplinary approach to the solution of the problems of ethno-national rivalry and contradictions, dominating in the world. Although the roots of Eurasian arts goes back to Aristotelian-Avicennian tradition, created in Central Asia (CA) of the eve of the last millennium, the evidence of that common tradition: archaeological, philological, philosophical, linguistic, etc., interconnected with each other and recognized by the diversity of the academic schools of the last century, are not included into educational programs of the universities of the modern times. That miss, creating a gap in the world system of knowledge, restricts development of international affairs and diplomacy in its global significance. To bridge that gap, observing and analysing what was missed in the system of knowledge and how Eurasian arts communities are organizing themselves in CA of pre-soviet times, how they managed to develop through the last century and what is their perspectives now, in globalizing world, is the aim of this paper.
\end{abstract}

Keywords: Eurasia, Central Asia, Ibn Sina, jadidism, communities, music, literature, arts, Tajikistan

\section{Introduction}

Eurasian art communities, as a new cultural phenomenon of CA, formed within the jadidism-reformers ideas from the second half of the 19th century, developing in the 20th century, are gradually developing their networks within the nowadays globalising world. The main tools for this development during the last two periods were: the crucially changing realities after the October revolution and at the deeper level, responding to the needs of the grass-roots intellectuals for artistic self-expression. That accelerated development, however, was squeezed and smashed by Stalinist terror (Приказ НКВД № 00447, n.d.). A photo document of the first Institute of Arts, organized in Samarqand in 1926, with the shaded faces of the repressed musicians, is now preserved at the Z. Shahidi museum of musical culture in Dushanbe. Arrests and executions of the leading actors of culture in the 20s and 30s however, outwardly reinforced by fascism, continued through WW2 up to the 50s. Migration of huge numbers of academics and intellectuals, escaping from Russia and Europe to Central Asia, created a unique intercultural environment in the former "corners" of the Russian Empire, and forming a new dimension of academic thought, conceptualized literary/cultural history of the region, as a whole. That new formation, however, was based, mainly, on the process of collection, systematization and studying of manuscripts via the prism of European system of critical knowledge of the past, opening perspectives of Eurasian space of our own days. The aim of the project was to recognize the real CA intercultural, cosmopolitan, regional identity, inhabited by the first generation of poly-linguistic and open-minded

Munira Shahidi, Chair of the Z. Shahidi International Foundation, acc.member of Cambridge University. 
intellectuals. Though the very world "cosmopolite" was a strong "taboo" in the Soviet period, its basic elements, like openness, hospitality, poetics and musicality were attracting features of the local people for outsiders.

\section{Situation Tajik Artistic Communities Within Eurasian Studies}

One of the basic discoveries within Tajik-Persian literary thought of the last century, made by both Tajik, Uzbek and Russian researchers, was the realization that this literature described a diversity of images and ideas that came from cultures around the world: from Keykavus and Dariush, Aleksander Macedonian and Aristotle, Samanids and Avicenna and al-Biruni, Timurids and ibn-Khaldun along with musicians and tailors, doctors, cooks and a simple servant, all creating a fantastic mosaic of constant dialogue and discourses. The linking trend of that great literary mosaic was music and musician, while musical instruments were praised by poets in meaningful and colourful expressions. More than that, in many poems, music was described in its links with math, geometry, physics and astronomy. It was also realised that the written sources, originating from CA, are widely scattered around the world in three dimension: (1) via invaders and colonizers; (2) via migration of scholars, poets, musicians and dancers from CA through India, China, Russia, Iran, Turkey and the Arab world toward Mediterranean shores and further; and (3) through intercultural communication as an academic-educational dimension of the last decades of the Soviet and post-Soviet periods.

Although the two first dimensions are quite well studied mainly by art historians all over the Soviet space, the third one, which is connected with the constantly changing political and economic situations inwardly and outwardly, was developed just in the two last decades of the 21st century. The most positive tendency of that trend is that everybody, who has more or less educational and research experience, can participate in that process, both physically and virtually via hundreds of websites and networks.

In my critical observation of the process of Eurasian space-building in CA from the Timurids up to-day presented a few years ago in Dushanbe in the Forum of the Actors of Cultures and Arts, organized by the Swiss Agency for Development and Cooperation-I tried to outline the grass-roots of Eurasian theory in CA of the modern world, which is considered to start in the 14th-15th centuries and now is a central interest of the world society (Shahidi, 2010, p. 92). In the lively discussion of my presentation, Kyrgyz colleague, Tolon Toychiboev, pessimistically remarked that Eurasian communities in the region are declining and, as an example, he brought up the film festival in Almaty, which, according to him, depended only on the state budget and, thus, is framed rather by national interests, than all-regional and interregional ones (Shahidi, 2010, p. 92). Two years later, participating the Forum of Emerging Eurasian Markets in Astana, on September 10th and 11th, 2013 under the title Eurasia in XXI century: Leadership Through Renovation, I raised a problem of the marginalized knowledge about CA Eurasian culture in today's leading universities around the world. My remark has been promoted by a few colleagues from Europe, saying that CA studies and publications from Central Asia itself are not known in the programs of European universities. And that's true. Although Turkic-speaking people of CA are now more actively entering Europe, creating new Eurasian communities, the artistic capacity of Tajikistan is still making its first steps into emerging Eurasian markets. What are the reasons for that slowness? There are a number of them, but the main, to my mind, is traditional Euro-centrism which ignores any knowledge, which comes not within it's “own” borders. The strategy of the last century's Tajik intellectuals to gain space in the one sixth of world culture, developing national culture/arts and penetrating Russian culture through literature, music, theatre, paintings and cinema has been quite successful. There is one important point: marginalized from the cultural megalopolis of CA, such as Samarqand and Bukhara, hundreds of 
Tajik-speaking intellectuals migrated from these cities to newly born Tajikistan in the 20s and 30s and intensified their interests in academic research, concentrating mostly on written sources in Arabic and Persian. The change of script at the eve of the twentieth century across Central Asia from Arabic script into Latin and then Cyrillic, took Central Asian literature away from the common ground of Arab-Islam civilization. A European system of knowledge however, adopted partly via Russian comparative studies of East and West, was gradually developing, studying the roots of modern world literature and the existence of images and ideas of Tajik-Persian literature in a diversity of literary cultures. That means today's Tajiks are very adaptable when migrating around the world.

New Eurasian art communities have a particular mission: to unite people, less mercantile and more creative, to open a really new space of interacting and interconnecting arts, realizing the 'hidden' aspects of human psychology in this transitioning and transforming world. It is important to note, that the critical Avicennian approach to science and arts of the "first teacher" of the world—supposedly Aristotle—was to liberate ancient Greek thought from its national, geographic and political boundaries. That approach created a new art of self-expression in the middle ages, re-evaluated in Europe in the last century through the translations and poetical interpretations of Khayam, Hafiz and Mavlana Rumi by Fitzgerald, Goethe, Nicholson, Arberry and many others. The crucial change in Aristotelian "Poetics", made by Ibn Sina, was recognition of lyrics, or recognition of music as a link of matter and soul. That change crucially transformed the world literary process of the middle ages (Shahidi, 1986). The core of Eurasian poetics is the interconnecting of European and Asian cosmological traditions, and therefore sharing of knowledge - this begins with the commentaries of Avicenna to the "Poetics" of Aristotle. Of course, this process has always happened most easily via melody and rhythm—an Avicennian idea.

\section{Today’s Eurasian Art Communities: Protection and Investment}

The formation of Tajik-Eurasian arts communities has been traced and, gradually, local gatherings of poets, musicians, theatre actors and producers-according to Tajik composer Firuz Bahor, now living in Germany — have found their "own roof” at the Z. Shahidi museum of musical culture. ${ }^{1}$ Friendly gatherings of the musicians, poets and artists at the museum promote discussions of transformation of the classical maqam tradition of CA into polyphonic music, dimensions which have many aspects in common with Russia, China and India.

In October 8-11, 2015, in Zurich, Switzerland, an international conference was held under the title: "Central Asia in the XXI Century: Historical trajectories, contemporary challenges and everyday encounters". ${ }^{2}$ Drawing attention to the challenge of social and financial protection of the newly emerging Eurasian arts communities and highlighting my own efforts in this matter, I focused on the transformation of artistic thought during the last century, rather than artefacts. That protection now however, is restricted by insufficient financing of Eurasian culture/arts in CA because there is not an open approach to arts. Local governments are following European rivalry and contradiction in development regarding "others", rather than their "own" regional tradition of harmonising the diversity of cultures. That's the reason of the stagnation of the discussions

\footnotetext{
${ }^{1}$ Our friendly chat at his new place in Berlin, 2002 (?)

2 Munira Shahidi (Tajik-Slavic University, Tajikistan) Emerging new art communities in Eurasia. 14th Bi-Annual Conference of the European Society for Central Asian Studies (ESCAS), Zurich, Switzeland, Central Asia in the XX1century. Historical Trajectories, Contemporary Challenges and Everyday Encounters, 2015, Panel 65: Arts and Language in (post-) colonial situations
} 
of the problem of the ethic of financing of development, in general, on the university and academic levels. When I was a trainee at the Department of the History of Ideas at the Gothenburg University in the mid-90s, I was participating in a seminar on the discussion of financing ethics in Sweden, regarding the on-going reforms of universities. The Ministry of Finance, as well as the Ministry of Education, along with the administration of the Gothenburg University, the students and professors of the university, all together, were discussing the existing state budget for education. When I was back in Dushanbe, I informed the then Minister of Education of Tajikistan about this seminar, but the very idea of raising the issue of ethics of financing at a time of civil war within the country seemed impossible.

Formation of financial ethics in CA was hardly restricted during the Soviet period within the mono-cultural, strictly vertical power sharing. Although some artists, manipulating the overexposed system, were able to make a real contribution to the development of arts, the official approach to intellectuals as the "streak" of society, marginalized them from the political and economic reforms of the post-Soviet period. Now, despite the fact that reforms in the system of education is a mainstream of the economic policy of almost all countries of Eurasia and beyond, the cross-cultural and interdisciplinary approach to the development of knowledge via arts, is still not a central interest. Moreover, a certain stagnation of the development of regional arts in the case of Uzbek musical culture was put into discussion by Dilorom Karamatova and Nigora Khasanova (2015) a few years ago, stressing the lack of study of the musical criticism and that is, in a way, the reason for today's stagnation of musical culture in the country (pp. 422-442). I may say that the same situation is in Tajikistan. That lack of criticism in arts, in general, restricts participation of artists beyond the country and the region, slowing down investments into the arts and, respectively, closing the opportunity to make them profitable for the state (Umarov, 2001, pp. 25-34). Meanwhile, insufficient ethics of financing impacts the development of museums, theatres and libraries. The Z. Shahidi Museum of Musical Culture during the last thirty years has no capital repair and reform. Though the last two years' celebration of the composer Z. Shahidi, as a founder of national symphony and opera, is strong evidence of Eurasian musical culture and international interest of musicians and composers, the building of the museum is still as it was during the life of the composer.

My academic background as a researcher of British orientalism has opened for me two aspects of a European culture: curiosity for the "other" cultures, improving their “own”, and underestimating advantages of “other's” culture/arts, evaluating its cultural infrastructure as a source of national economical income. There are, however, two 'holes' in western orientalism, regarding the study of the literature/ arts of CA. First, western orientalism ignores modern literary/arts development of CA, which is Eurasian in its core. Secondly, the modern educational system as a global phenomenon is still based only on the European values. But the fault of cultural policy within Central Asia and towards Central Asia is, first of all, stagnation in its historical values rather than developing them via intercultural communication regionally and globally and the dissolution of the all-regional intellectual potential, according to the old and odious scheme of ignoring the 'others' rather than domesticating their achievements.

\section{A Place for Musical Culture in Tajikistan}

My first "face-to-face" meeting with British and other European researchers in oriental studies started in 1986, when I was invited to the Congress of Orientalists in Hamburg, Germany. Participation in the discussions of the diversity of academic schools of western orientalists, however, gave me a blended sense of admiration 
and disappointment. I was delighted to see so many eastern and western schools focused on diversity of aspects of so to say, "oriental" cultures, including my own native Tajik-Persian literature, but worried by the absence of the really interdisciplinary approach to the development of the deep human communications during these conferences and academic conferences (Shahidi, 2001). On my way back to Dushanbe via Moscow, I was given an advanced copy of the Russian musicologist Elena Orlova's work under the title of "Ziyodullo Shahidi", which I read on the plane. My father had just recently passed away in sadness and loneliness: the rapid migration of professional musicians due to the economic crises of the 80s and raising tension on the borders with Afghanistan, as well as marginalization of the modern music from its local context, accelerated his demise. I was reading the book with pain in my heart, when the man sitting next to me began to speak with me. He was the late Head of Supreme Soviet of Tajikistan, Goibnazar Pallaev. Though I was not traditionally polite (perestroika had already impacted me), we discussed the complicated status of innovators in arts like my father until the plane landed. Our farewell ended with the idea of creating the Z. Shahidi Museum of Musical Culture in our private house and Pallaev offered his support. After getting consensus from my mother and family, I began a new activity as a director of the newly organized museum and an initiator of a new local Eurasian art community.

Practical implementation of my knowledge within the real Eurasian space however, started in Europe, when I was invited to participate at a Sufi gathering in Sweden on the eve of the 90s. For the first time I saw the community of European Sufis. My presentation, regarding the impact of mystical motives on the formation and re-formation of the modern/contemporary arts in Tajikistan like my father's opera "Komde and Madan”, based on the poem of Sufi Persian-speaking poet of India Abdulqadir Bedil, was met with great interest by the European Sufi community. That community consisted not only of the converted European Muslims, but was also open for professors and students in music and arts from Stockholm and Gothenburg universities. That first intercultural communication gave a crucial push for my professional contacts and I was invited as a guest-professor at Gothenburg University, in the department of the "History of Ideas". In comparison with the universities of the Soviet and post-Soviet space, the arts and artistic activity are integral parts of the universities of Europe. I know a number of students from CA, participating in artistic activities of these universities. These students are gradually changing perception of the region inwardly and outwardly not just as a cross-roads of diversity of cultures, capable of self-harmonising, but also re-evaluating that capacity within European reality.

One of the contemporary trends of the new Eurasian culture/arts communities that interests me is generational transformations in musical style. Through my family of composers (my father, my brother and now my daughter are composers), I am trying to understand common and specific features of the composers of three generation, focusing on their "own” style of self-expressions. The technique of self-expression, however, forms rather due to education than by family affiliation, though the family and an environment have their own impact within the process. During the last decades of my international life, I have seen a number of artists and musicians, promoting fusion of their "own” music into the rapidly changing contemporary world.

The brightest examples of the performing of contemporary Eurasian music are the symphony orchestra under the conductor Philip Mackenzie in Britain; Norwegian sax player Rolf-Erik Nystrøm; Karatygina, an art-manager who provided the international conferences "The World Musical Map" in Moscow Conservatoria; ensemble "Gruazar" in Canada; ensemble Maroon Town; Central Asian Theatre company "Orzu” in London; as well as experimental theatres of Kazakhstan, Uzbekistan, Tajikistan and Afghanistan, biennale of the painters of Asia and Europe in Istanbul, Tehran, Tokyo, Delhi and Beijing and other famous and not yet known 
centres and actors of musical culture. By collaborating locally and globally, these cosmopolitan artists are mastering their "own" world in close connection with the "others". But their activity is designed not merely to sell their artistic product in a newly emerging Eurasian markets. Their art strongly affects people by releasing them from their "own” national, religions and geographical boundaries, bringing them together and uniting their efforts to create an intellectual and creative solidarity locally and globally.

\section{Arts and Culture as Solutions to Global Challenges}

Most disciplinary academics of our time assume that in the epoch of the formation of new universal values, economy and policy are more important than culture and arts for solutions of the problems of poverty, natural catastrophes and ethnic conflicts. These opinions might be improved if we re-evaluate the second part of the last century of CA, when human studies, including art studies, were turned into a strong power for humanization of the societies all over the Soviet space.

As a result of four to five decades of academic research, the cultural industry has been finding increasing significance in CA. Legalization of the deep interconnection and interpenetration of Tajik-Persian and Uzbek-Turkish literatures in the case of Jami and Nava'i or the style of life of Ibn Sina/Avicenna or Ahmadi Danish and Mirza Sirojiddin Bukhari, became a mainstream of the academics and writers of the region (Hakim, 1992). Promoted by Abay, Ayni, Mukhtar Auezov, Khamza Khakim-zade Niyazi and followed by Mirzo Tursun-zoda, Chingis Aytmatov, Ashrafi, Jubanov, Shahidi, Khoshmuhammedov, Kimyagarov, Tohir Sobirov and others, the culture/arts made crucial contributions in the raising Eurasian arts communities of their own time. Politically and culturally, the mission of CA during the "cold war" of superpowers was to resist militarization of the minds, re-generating and re-establishing human values in the region and beyond.

Now, after dissolution of the Soviet system and re-opening of the region to the world, the huge natural resources of oil, water, minerals and organic food have turned CA into an attractive source of income for developed countries. That purely mercantile approach to the region as a whole, creating ongoing tension between the people and their official state parties, especially when the latter turn a blind eye, sensing the danger of the "others", not their own people, mastering natural resources, is a danger for peace and development.

In the aftermath of the 1992-1997 civil war in Tajikistan, much scholarly and journalistic attention was focused on the arms and weapons, left in the territory of Tajikistan after the Soviet aggression in Afghanistan. While the question of the causes of the civil war in Tajikistan is important in order to prevent further conflicts, it is also essential to discuss the comparative question of why does the peace-building potential of the region prevent the interethnic clashes, although it does not do so in Afghanistan that still suffers from the inner contradictions. The current trend of the human studies in Tajikistan, re-evaluating the crucial periods of the Tajik cultural development, is opening the real situation of the eve of the last century. One of the examples of that type of re-evaluation and re-research of the discourses is publication of the articles and papers of the intellectuals of Samarqand of those times: "Tajik language in the discourses. Collection of articles of the early 20th century" (Tajik language in the debates, 2007). The book outlined the discourse of the time, which was either to change the Tajik script and raise the speed of adopting modern technology of Europe, developing own human and cosmopolitan principles of the region, or to slow down common regional need to change. Adopting European system of knowledge with all its wrongs and rights however, gave a crucial push for development of arts. More than that, re-thinking "own" literary tradition, mirrored in the "other" cultures, for example, highlighting the imaginative dialogue of Hafiz and Goethe in the "Western-Eastern Divan" (1819) or 
identifying the images of Rustam and Ruslan in Tajik and Russian mythology, Tajik intellectuals gradually began to sense the common Eurasian culture/arts space.

\section{Central Asian Contributions to Today's Global Space of Arts and Culture}

The common aspects of the literary-cultural thoughts, ideas, imagination and creativity in Central Asian countries have been indirectly affecting social progress, shifting cultural behaviours. Forming and re-forming within the organic soil of the cosmopolitan Sufism, shared by neighbouring countries, particularly Afghanistan, Iran, Pakistan, as well as India and Turkey. These studies, softening the inner cultural rivalry and contradictions of the Soviet system and beyond, were promoting the international character of the national/regional arts. Now, after the collapse of the Soviet system, Central Asian culture/arts are gradually implementing their own innovative values into the global space in three dimensions: (1) theatre; (2) paintings; and (3) music.

Farrukh Kasimov has been reforming and releasing the national theatre from the frames of the Soviet ideology. Using the traditional "usul"-"method" of mirroring "one" character in the "other", as well as demonstrating the crucial transformation of divine love into the terrestrial, Kasimov masterfully uses the images of a Sufi poet in love with an ordinary girl and Shakespeare's "Romeo and Juliet”. Touring in many countries of Asia and Europe in the 1990s and the beginning of 2000, including Iran, Afghanistan, Belgium, Germany, and Russia, Farrukh made a really appraising Eurasian innovation.

A new independent producer-Barzu Abdurazakov, has further developed this innovation in more modern terms. His "Madness. Year 93" (Bezumie. God 93iy) about the events of the French revolution, based on the combined texts of Pitera Vays and Victor Hugo, as well as "migrants" of the Polish writer Slawomir Mrozek, raised the meditations about "own" problems of power and reality via sensing the "others". Demonstrating the complicated issues of interconnection and interpenetration of the over-expectations of the masses from the revolutionary changes and their disappointment at the behaviours of the political leaders, Barzu uses the ideas of the European authors, expressed within the national Tajik characters. This fusion creates an imaginary common Eurasian space.

In Kyrgyz theatre, Abdurazakov staged a play_- “The long way to Mecca” (Dolgaya doroga v Mekku) based on his own writings. In the recent festival of theatres "Art-okraina", the best spectacle was again by Abdurazakov and again was based on the Polish author Yan Tomash Gross's “Neighbours” (2000), which opened a totally other version of the mass murder of Jews in the town of Jedwabne, Poland. Based on "Neighbours", T. Slabodzyanek, a Polish writer, has written a performance, under the name "Our class", which under the name "Classmates. The lessons of Life" has been staged by Barzu. The Russian critic Marina Dmitrievskaya (2015) states the following:

Barzu Abdurazakov builds the performance, like a score, consisting from choirs and solos, as a rapid flow of attraction and repulsion from the gradients of quarrels and fights for unity, polyphonic story about the history and people in it... when all actors are like keys under the fingers of the musicians, but every key has it's own sound... (Dmitrevskaya, 2015, pp. 25-34)

Producers, musicians and actors from around CA, particularly Turkmen, Uzbek and Kyrgyz have and still are coming to Tajikistan to collaborate and exchange knowledge, while Barzu and other Tajik producers are working in Kyrgyzstan, Uzbekistan and other counties, receiving awards for their work. The tribute to promote the new movement in its regional activity belongs, however, rather to international organizations, such as UNESCO and the Swiss Office for Cooperation in Tajikistan. 


\section{Understanding Central Asian Arts and Culture}

Representation of Tajik artists is also central to interests of creating an international community. This mode of expression in the case of Tajik and Turkish artists inspired a producer from Columbia, Fabiola Agudelo Henao to create a project with the aim to observe "what's going on" now in arts of these two culturally close countries. Researching diverse methods of combining imaginary and real words, two art researchers from Tajikistan and Turkey, Lutfia S. Ayni and Pelin Sahin Tekinalp, identify the changes in the techniques and styles of expression of artists from Tajikistan and Turkey, studying in Russia and Europe. According to Pelin Sahin Tekinalp, Turkish artists, like Osman Hamdi, formed in both Turkey and European schools of arts, "broke new ground within the context of Turkish painting”. Characterizing the works of Tajik artists, Lutfia S. Ayni instead highlights the impact of the modern Russian schools of painting (Paintings and Painters of Tajikistan and Turkey, 2009). Reflecting on the impact of the modern Russian and European schools of paintings on formation of national artists, however, the named critics missed to mention aspiration of the modern avant-garde artists of Russia and Europe from the classical Persian artists, like Behsad and his followers. Although V. Kandinsky, the famous Russian avant-gardist, has been deeply inspired by the colours of Behzad and expressed that inspiration in one of his letters to his European colleagues, that evidence has been missed by the contemporary critics.

Generally speaking, Central Asian art in its best appearance, cannot be conceptualized in traditional European classification. Artistic thought in CA is not limited with the terms of Islamic, Christian, Jewish or Buddhist arts. It rather breaks the mono-cultural frames, either national or religious, combining two or more cultural traditions within the common space of the ethnic and national diversity. This combination is proved by archaeological evidence with various elements of the Greek theatre and the monuments of Buddhism, Jewish cemeteries, neighbouring Christian churches and Muslim mosques on the territory of Tajikistan—all along the countries from CA toward Mediterranean shores.

One of the most famous sources of inspiration for nowadays poets, musicians and painters of the world is the poetry of Jalaluddin Rumi. His art inspires both artists and ordinary people, to embrace the world in all its diversity. Born on the shore of the river Vakhsh (nowadays Tajikistan), the poet migrated away from the Genghis Khan invasion with his father's family, passing a long way through Samarqand toward Anatolia. A few years ago, following his route to Konia, I tried to imagine, how he was meditating over the ruins of the Greek and Roman theatres, seeing the ruins as the evidence of cultivation of the superiority of "ones" on the 'others'. I sensed the poet and great humanist, imagining all dramatic wars and violence were influencing his view of the world. The innovation was to break the hierarchy of power, turning the verticality of power into horizontal human communication. The core of the change was to be able to create a common space between "me" and "you". This idea became the core of Mawlana's "Book of Love", which is a contemporary interpretation of his "Mesnevi-i Ma'navi”- “The Poem of Secrets”, dedicated just to a traveling dervish, Shamsi Tabrizi. The poet does not comment if his friend is Muslim, Christian or Buddhist. This new concept of the "other" in "himself", regardless of his language, faith or nationality, is a starting point for the dialogue of diversity of images, personalities, animals, flowers and the nature, as a circling whole. The poem, which has been adopted by the English-speaking world via numerous translations, the best known translations by R. Nicholson and John Arberry, as well as by American poet Coleman Barks. Barks initiated a new process of 
creation of an "American Rumi”. ${ }^{3}$ Almost two centuries before, Goethe (1814-1815) in his "West-East Divan", offered an idea of "poetical twins", describing himself and Persian poet Hafiz in the dialogue of "seen” and "unseen” poets. Almost at the same time, the Great Russian writers and poets, including Tolstoy, Pushkin, Turgenev, created a similar dialogue between real and non-real senses of the changing world. Recognition of these circling literary images in the second part of the last century as a common Eurasian space is opening the new reality of our own days.

But this reality did not come by itself. An example of the ups and downs of the second part of the last century can be seen in a sharp discourse between Ibrahim Purhadi, a librarian, of Iranian origin, at the US Congress and Mirzo Tursun-zade and Ghafurov, via a popular journal of Soviet times "Ogonek" in the 60s. The former offered his view on the development of the Sufi cosmopolitan poetry in modern/contemporary Tajik poetry, bringing as an example three poems of Mirzo Tursun-zoda: "Sitorai man" (My star) "Kishloqi shumo" (Your village) and "Khonai mo" (My home). But the political correctness did not allow Tursun-zoda and Ghafurov to support or develop the American's idea. They rejected any links of their "Soviet” culture with Sufi poetry, insisting on the values of "realistic", secular modern Tajik poetry. Thus, the efforts of building intercultural communication have been temporally closed. Now, when the space-building is open for creating “own” marketing, development is still too slow.

The main reason is the lack of real management, which could organize the "selling" of Eurasian artefacts with the right interpretation of the arts. The second reason is the Soviet framing of the national identity of most poets, writers and journalists.

The new play of Dushanbe's Lohuti theatre "Zindagi noma” (Life story), dedicated to the centenary of Z. Shahidi and meant to be an artistic re-evaluation of the process of transformation of identities via music, starts with the arrest of the father of the future composer by the people "in dark". Surrounded by the men wearing black clothing with cold, iron faces, the father quotes the famous lines of Nizami's poem to his son: "remember, that the science of music is higher than the wealth of poetry". Re-evaluation of this remark in the 50s and 60s initiated by the composer, however, was not reflected in the play. Instead, a group of actors demonstrated the "victory" of the composer with the cheers of his friends in a very "traditional" Soviet manner.

Ziyodullo Shahidi International Foundation has launched a new project- "Music of the Silk Road from the peace-building perspectives of Central Asia, dedicated to centenary of Ziyodullo Shahidi" under the auspices of UNESCO. The aim of the project is to identify the music of Central Asian countries as a generator of new Eurasian music, started in China and India in the first half of the last century, along with the Russian and European composers. Inspiring grass-roots musicians gives a significant push for the newly rising Eurasian communities of our own days. Hopefully, this upcoming event will highlight the state of regional Eurasian musical culture as a tool for building a New Silk Road, where culture/arts will take their own, original place.

\section{Conclusion}

In this paper I have tried to show that a deeper understanding of Central Asia's past and it's contact with the outside world is crucial to opening up perspectives on opening the world as it was traditionally, but within today's new, more globalising conditions. We need to rediscover the world in all its diversity, intercultural complexity and interconnection. Three challenges of globalizing world must be put into the centre of the

\footnotetext{
${ }^{3}$ Retrieved from http://www.poetrysociety.org/psa/poetry/crossroads/interviews/questions_of_faith_coleman_barks/
} 
contemporary discourses: (1) recognition of the newly emerging Eurasian communities; locally and globally; (2) inclusion of Aristotelian-Avicennian tradition of development, as a product of Central Asian minds, in university courses regionally and globally; and (3) to realize the common space of Eurasian cosmopolitan identity as the organic, original tool for development of peace-building movement within the region and the global world.

\section{References}

Dmitrevskaya, M. (2015). Inescapable. Asia Plus. 13

Dilorom, K., \& Nigora, K. (2012). Musical culture in Uzbekistan after independence. Eurasia twenty years after. In A. Sengupta, S. Chatterjee \& S. Bhattacharia (Eds.), Maulana Abul Kalam Azad Institute of Asian Studies (pp. 422-442). Kolkata.

Hakim, M. S. (1992). Tuhafi ahli Bukhoro (Тухафи ахли Бухоро). Dushanbe: Adib.

Hermann, W., \& Linn, J. F. (Eds.). (2011). Central Asia and the Caucasus: At the crossroads of Eurasia in the 21st Century. India: SAGE Publications.

Приказ НКВД № 00447. (n.d.). Online. Internet. 14th Bi-Annual Conference of the European Society for Central Asian Studies (ESCAS), Zurich. Retrieved September 16, 2015, from https://ru.wikipedia.org/wiki/Приказ_НКВД_№_00447

Shahidi, M. (2001). Central Asia and Europe: Dialogue of cultures or improvement of modern demосrасу (Центральная Азия и Европа: Диалог культур или совершенствование современной Демократии). Fonus, 3, 36-46.

Shahidi, М. (1986). Ибн Сино и Данте. Душанбе, Ирфон.

Shahidi, М. (2010). The resumption of intercultural dialogue in Central Asia: From theory to practice (Возобновление межкультурного диалога в Центральной Азии: от теории к практике). In Regional Forum of culture and art. Unity in Diversity (Региональный Форум Деятелей культуры и искусства. Единство в многообразии) (pp. 80-84). Dushanbe: Swiss Agency for Development and Cooperation.

Tajik language in the debates (Забони точ икй дар мабнои мубохисахо). (2007). Dushanbe: Irfon.

Turkie ve Tacikistan'da Resim San’ati ile Ressalar (Paintings and Painters of Tajikistan and Turkey). (2009). Искусство живописи. Художники Турции и Таджикистана. Turkie.

Хоч имухаммад Умаров. (2001). Точ икистон ва бозори ч ахонй. ј. Fonus, 3, 25-35. 